\title{
Comparative Study of Pre-Test Score and Post-Test on Regional Health Planning Training
}

\author{
Silviani Kesuma ${ }^{1}$ Supriyono $^{2 *}$ \\ 1 Widyaiswara Associate Expert, Resource Development Agency Regional Human of Central \\ Sulawesi Province, Indonesia \\ ${ }^{2}$ Widyaiswara Associate Expert, Central Java Regional Human Resource Development \\ Agency, Setiabudi No. 201 A Street Semarang, Indonesia \\ *E-mail: supriyonontr@yahoo.co.id
}

\begin{abstract}
This study aims to determine the differences in the results of teaching and learning training in regional health planning (Renkesda) in Batam National Health Training Center (Bapelkes) in 2016. To compare the results of the pre-test and post-test results after training. This type of research is cross sectional. The population in this study were all participants in the Renkesda training. The sample in this study was saturated, where all participants were taken as samples, with the number of respondents as many as 60 people. Before being subjected to treatment the two classes ( $\mathrm{X}$ and $\mathrm{Y}$ ) tested their homogeneity with different mean tests based on the average value of learning outcomes. The data analysis technique used was the Wilcoxon Signed Ranks Test which previously tested normality and homogeneity. Data collection methods are tests, observation, and documentation. The results of the study at the $95 \%$ significance level obtained $\mathrm{p}$-value 0.556 and $0.908>0.05$. Thus it can be said that there were no differences in learning outcomes of class $\mathrm{X}$ and class $\mathrm{Y}$. Furthermore when compared between pre and post-test, the following results were obtained: in class $X \mathrm{Z}$ value of $-4,795$ with a $\mathrm{p}$ value of $0,000<0,05$ and in class $Y Z$ value of $-4,715$ with the value of $0,000<0,05$. Based on Wilcoxon Signed Ranks Test test results, obtained $Z$ value of $-4,582$ with a p-value of $0,000<0.05$, so it can be concluded that there are significant differences in the scores of the pre-test and post-test in class $\mathrm{X}$ and class $\mathrm{Y}$
\end{abstract}

Keywords : Renkesda, pre and post-test, comparative study

\section{Introduction}

The implementation of development in the health sector in the regions is very much determined by the quality of planning and budgeting, which in this case as the spearhead is the district and city governments. Therefore, so that the results of development can be felt by the community, it is necessary to have reliable planners at the local level (Ministry Of Health, 2016).

Law No. 23 of 2014 article 16, concerning Regional Government, so that the central government sets the Norms of Guidelines and Criteria (NSPK), and conducts supervision and guidance which is the region's affairs and authority. Furthermore, Article 68 mandates the existence of sanctions imposed on regional heads if they do not implement the NSPK as outlined in the national strategic program. Therefore it is deemed necessary for the central government to provide information to local governments in the form of socialization, dissemination, workshops, and training. (Law Number 23 Of 2014). 
Batam Health Training Center as one of the institutions providing education and training engaged in health took part in regional health planning. A tangible manifestation of the role mentioned above is in the form of training. One such training is Regional Health Planning (Renkesda). Training will have meaning if it is evaluated regularly and followed up by user institutions. One form of evaluation carried out in education and training is pre-test and posttest. From the initial observations in training, the results of the pre and post-test have never been evaluated and followed up. Therefore, the researcher will explore the differences between the pre and post-test scores in the regional health plan training. The purpose of this study was to determine differences in the value of pre and post-test scores in regional health plan training in Batam health training centres. Many studies on research that explore the evaluation. However, there are very few that discuss the evaluation of pre-test and post-test in research, especially those carried out at the Batam Health Training Center. In this study, the hypothesis to be tested is "There are Differences in Pre and Post Test Score Scores in the Regional Health Plan Training. The hypothesEs is the original (Ha). For hypotheses testing is changed to zero hypotheses (Ho) so that it becomes "No Difference in Pre and Post Test Score".

\section{Materials and Methods}

\section{The definition of training}

The definition of training as stated in the large Indonesian dictionary (1989) is a process or activity of carrying out activities or work. Meanwhile, according to Bernadin (1998), training in a variety of introductory efforts to develop the performance of workers in the work they carry. Law on the National Education System Number 20 of 2013, training is a conscious and planned effort to shape the character of students to develop their potential.

\section{Definition of evaluation}

One measure to measure the progress of the teaching and learning system is through an evaluation. The steps in conducting an evaluation are preceded by collecting data and information. The purpose of the evaluation is to find out the success or failure of learning and the steps that will be applied in further learning. This measurement and assessment is the most important element in the evaluation process. The measurement in this evaluation is related to the measurement of quantitative data, while the assessment is related to the measurement of quality (Arikunto, Fundamentals of Educational Evaluation, 2019).

Many measuring tools are used to determine the development of the learning process, one of which is a test. According to (Arikunto, Fundamentals of Educational Evaluation, 2019), there are six types of measuring devices that can be used to determine the development of the teaching and learning process, is (1) Test selection, this test is used to select or choose the best of the many candidates who take the test or better known as the screening test. (2) Initial test or pre-test, this test is used to determine the initial ability of participants in participating in learning programs. (3) Final test or post-test, the final test is carried to find out whether all subject matter has been mastered by the learning or training participants. (4) Diagnostic test, in the teaching and learning process, this test is often used to determine 
precisely the level of difficulty with certain materials or subjects faced by learners. (5) Formative tests, In the teaching and learning process, this test is used to determine the ability of students during the learning process. Generally, formative tests are conducted in the middle of the semester. (6) Summative test, this type of test is carried out at the end of the learning process where all course material is given, which is generally given in the written form. and more difficult than formative test questions. This summative test is given to determine the level of success of students after participating in the learning process (Amirono \& Daryanto, 2016).

As one of the measurement tools in evaluation, pre-test, and post-test is used to determine the level of success of a learning process. The pre-test is given before the learning process, while the posttest is given when the learning is finished (Purwanto, 1998). As one type of evaluation, pre-test and post-test are given to know with the aim to the extent of the development of participants' knowledge of the material to be and has been taught. The pre-test is given to explore the level of knowledge of trainees before the material is given. While the post-test is used to detect the extent to which the material delivered by the facilitator to students or training has been well mastered. (Sudijono, Introduction to Educational Evaluation, 2018).

\section{Learning process}

Changes occur in the learning process through three stages, namely assimilation, accommodation, and equilibration. Assimilation occurs because of the process of unifying new information into new domains of knowledge (cognitive) that already, and exist. Whereas accommodation is a continuation of the process of assimilation, namely the change of the cognitive domain into a new situation, then the equilibration process is an adjustment that occurs and takes place continuously between assimilation and accommodation. The test is an example of a change that begins with the process of assimilation, accommodation, and equilibration obtained by students to get new information so that the material or material to be taught can be adapted to students' abilities. Adjustments occur in the cognitive domain of students because the material has not been mastered at all by students (Suciati and Prasetya Irawan, 2017).

This study using a comparative study (comparative study), and the approach used is crosssectional, where the data is taken within a certain time, with the population is all participants of the Renkesda training centres Batam health training. Sampling method, with saturated sample technique where the score of pre-test and post-test scores were obtained from all participants who took part in the training, amounting to 60 respondents divided into two classes, class $\mathrm{X}$ and class $\mathrm{Y}$. Data were obtained through literature studies and search for processed primary data. then the data, analyzed univariately to know the general description of the frequency distribution of respondents' general characteristics and dependent variables. Furthermore, to determine differences in the value of pre and post-test scores, using the Wilcoxon Signed Ranks Test (Sudjana N., Basic and Teaching and Learning Process, page 22, 2018). 


\section{Result and Discussion}

\section{Characteristics of respondents}

The age of respondents in class $\mathrm{X}$, dominated by the age group 31 - 35 years, amounted to $33.33 \%$, the youngest age was 24 years old and the oldest was 51 years old, with the majority of the education level was strata one of $70 \%$, while in class $\mathrm{Y}$ it was dominated by the age group 36 - 40 years, amounting to $30 \%$ of the youngest age is 28 years and the oldest is 48 years with the level of education of most strata one which reaches $53.3 \%$.

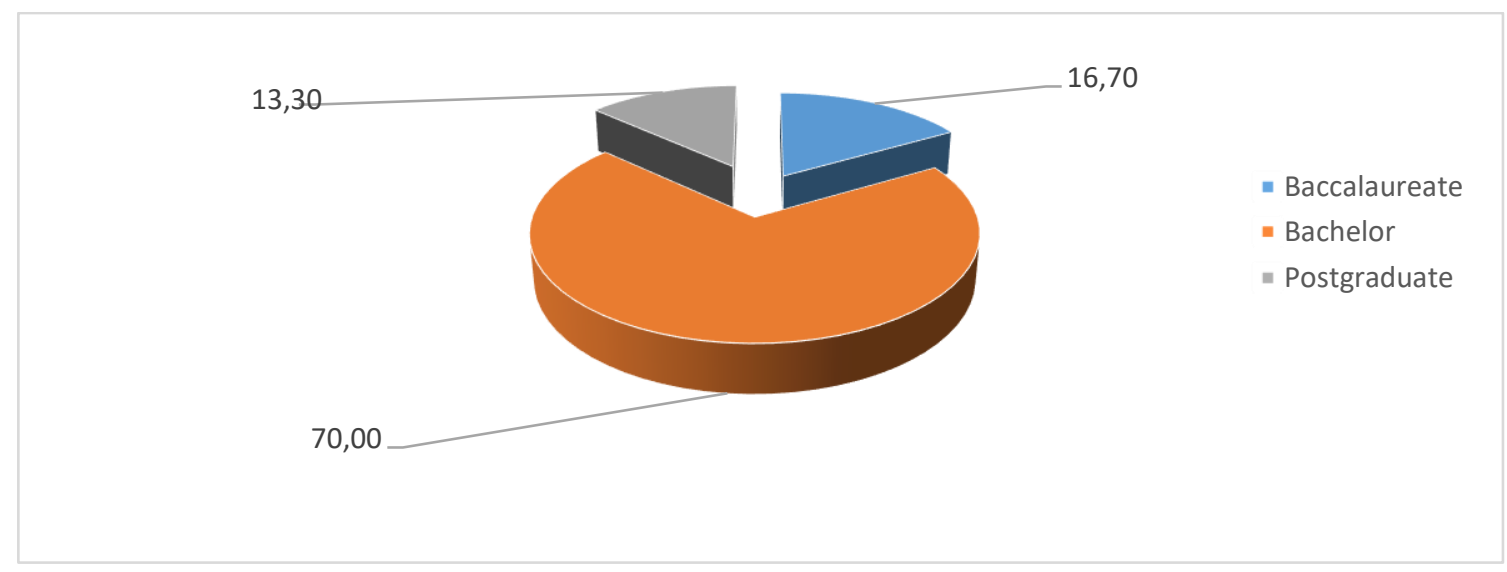

Fig 1. Education level in class $\mathrm{X}$

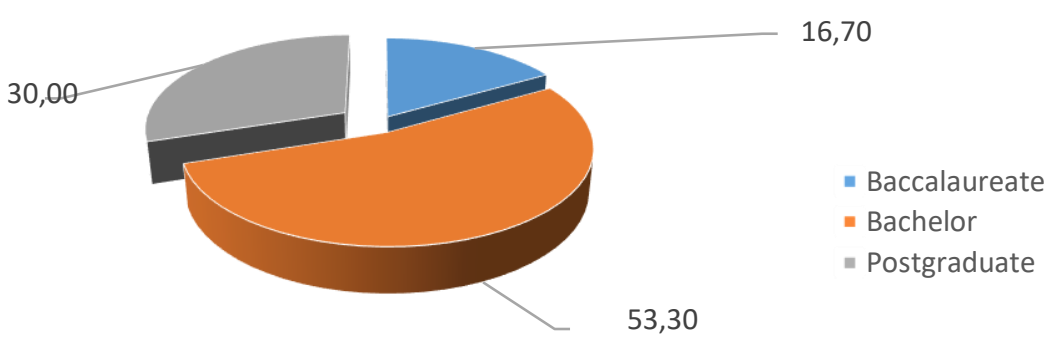

Fig 1. Education level in class Y

The pre-test results, from 30 questions tested in class $\mathrm{X}$, the average value of 34.83 was obtained with a standard deviation (SD) of 7.598. The lowest pre-test value is 25 and the highest is 55 with a variance of 57.730. in class, Y has an average value (mean) of 36.33 with a standard deviation (SD) of 11.666. The lowest pre-test value is 10 and the highest is 55 with a variance of 136,092 . Then the post-test results, from 30 questions tested in class $X$ have an average value (mean) of 63 with a standard deviation (SD) of 7.834. The lowest pre-test value is 50 and the highest is 80 with a variance of 61,379 . in class, Y has an average value (mean) of 63.33 with a standard deviation (SD) of 8.023. The lowest post-test value is 50 and the highest is 85 with a variance of 64,368 . 
Table 1. The pre-test scores of class $\mathrm{X}$ and class $\mathrm{Y}$

\begin{tabular}{cccccc}
\hline description & lowest & highest & Mean & SD & Varians \\
\hline Pre-test class X & 25 & 55 & 34,83 & 7,598 & 57,730 \\
Pre-test class Y & 10 & 55 & 36,33 & 11,666 & 136,092 \\
\hline
\end{tabular}

Table 2. The post-test scores of class $X$ and class $Y$

\begin{tabular}{lccccc}
\hline \multicolumn{1}{c}{ description } & lowest & highest & Mean & SD & Varians \\
\hline Pre-test class X & 50 & 80 & 63,00 & 7,834 & 61,379 \\
Pre-test class & 50 & 85 & 63,33 & 8,023 & 64,368 \\
$Y$ & & & & & \\
\hline
\end{tabular}

\section{Normality test}

Normality test is intended to test the normality of data obtained from research results. This normality test is also to find out whether the sample can represent the population or not, with the results as in Table 3.

Table 3. The normality test of score pretest and posttest in class $X$ and class $Y$

\begin{tabular}{|c|c|c|c|c|}
\hline Class of & Data & X2 hitung & $\mathrm{X} 2$ table & Distribution \\
\hline \multirow{3}{*}{$X$} & Pre-test & 0,530 & \multirow{5}{*}{0,248} & Not normally \\
\hline & Post-test & 0,753 & & Not normally \\
\hline & & & & \\
\hline \multirow{2}{*}{$\mathrm{Y}$} & Pre-test & 0,563 & & Not normally \\
\hline & Post-test & 0,774 & & Not normally \\
\hline
\end{tabular}

\section{Homogeneity test}

To determine whether the sample comes from homogeneous variance, a homogeneity test is performed, with the results as shown in Table 4.

Table 4. The homogeneity test for variance

\begin{tabular}{|c|c|c|}
\hline \multicolumn{3}{|c|}{ Homogeneity test of variance pre-test } \\
\hline \multirow{2}{*}{ Statistics } & \multicolumn{2}{|c|}{ Class of } \\
\hline & $\mathrm{X}$ & $\mathrm{Y}$ \\
\hline Variance & 57,730 & 136,092 \\
\hline F count & \multicolumn{2}{|c|}{0,433} \\
\hline F table & \multicolumn{2}{|c|}{1,039} \\
\hline Conclucion & \multicolumn{2}{|c|}{ Homogen } \\
\hline \multicolumn{3}{|c|}{ Homogeneity test of variance post-test } \\
\hline \multirow{2}{*}{ Statistics } & \multicolumn{2}{|c|}{ Class of } \\
\hline & $\mathrm{X}$ & $\mathrm{Y}$ \\
\hline Varians & 61,379 & 64,368 \\
\hline
\end{tabular}


F count $\quad 0,002$

F table 4,487

Conclucion Homogen

\section{Hypotheses test}

The Wilcoxon Signed-Rank test in the pretest aims to further believe that class $\mathrm{X}$ and class $\mathrm{Y}$ have the same initial ability. Whereas the posttest result is to show the difference in class $\mathrm{X}$ learning outcomes compared to class $\mathrm{Y}$ that follows the learning process. If $\mathrm{p}<0.05$ means there is no significant difference and vice versa if $p>0.05$ means there is a significant difference between class $\mathrm{X}$ and class $\mathrm{Y}$

Table 5. The analysis of wilcoxon signed rank

\begin{tabular}{cccccccc}
\hline Description & Class & $\mathrm{n}$ & Mean & Varians & Count it & Alpha & Conclusion \\
\hline Pre-test & $\mathrm{X}$ & 30 & 34,83 & 57,730 & 0,556 & & Not Significantly \\
& $\mathrm{Y}$ & 30 & 36,33 & 136,09 & & 0,05 & $\begin{array}{c}\text { different } \\
\text { Not Significantly } \\
\text { Post-test }\end{array}$ \\
X & Y & 30 & 63,00 & 61,379 & 0,908 & & different \\
\hline $\begin{array}{c}\text { Pre Post- } \\
\text { test }\end{array}$ & $\mathrm{X}$ & 30 & & & 0,00 & & \\
$\begin{array}{c}\text { Pre-Post- } \\
\text { test }\end{array}$ & $\mathrm{Y}$ & 30 & & & 0,00 & & \\
\hline
\end{tabular}

Based on the calculation of the Wilcoxon Signed Rank Test at the time of the pre-test, the results obtained $Z$ value of -0.588 with a $p$-value of $0.556>0.05$ means that there is no significant difference between the pretest group in class $\mathrm{X}$ and class $\mathrm{Y}$. However, although there are no significant differences, the value of pre-test in class $\mathrm{Y}$ is more diverse. There is no difference in the results of this pre test score, because the participants tend to be homogeneous and from different backgrounds such as the education taken and work experience of each worker.

For post-test, the $\mathrm{Z}$ value of -0.115 with a p-value of $0.908>0.05$, there was no significant difference between class $\mathrm{X}$ and class $\mathrm{Y}$. However, although there was no significant difference, the pre-test value in class $\mathrm{Y}$ was more diverse than class $\mathrm{X}$, with SD grades $\mathrm{X}$ 7,598 and Y classes 11,666. Post-test scores in class Y are also more diverse. At the end of the lesson, the participants received an evaluation in the form of a post test. From the evaluation results, there was no significant difference between the two class groups. Many influencing factors include participants getting the same material, and the facilitator already referring to the lesson plan that has been prepared before giving the lesson. 
Furthermore, when compared between pre and post-test, the following results were obtained: in class $\mathrm{X}$ the $\mathrm{Z}$ value was -4.795 with a p-value of $0.000<0.05$ and in class $\mathrm{Y}$ the value of $Z$ was -4.715 with a value of $0.000<0.05$. Based on the results Wilcoxon Signed Ranks Test, obtained a $Z$ value of -4.582 with a $p$-value of $0.000<0.05$, so it can be concluded that there are significant differences in the pre-test and post-test scores of regional health planning training in class $\mathrm{X}$ and class $\mathrm{Y}$. It can be said that class $\mathrm{X}$ and class $\mathrm{Y}$ get the same material in following the health planning training learning process at the Batam national health training centre.

Learning outcomes are one of the tools to measure whether educational goals have been achieved with what is expected. The results achieved from the learning process are expected to be used as a reference in efforts to achieve competencies that have been set (Sudjana N. , Basic and Teaching and Learning Process, page 22, 2018). Meanwhile, according to Sri Rumini, learning outcomes are human capacities shown in daily behaviour. Behaviour is an activity that is shown by students related to the learning outcomes obtained during the learning process. (Sri Rusmini, et al, 2019).

There are three areas of mental development which include behaviour, knowledge, and attitudes. While from the standpoint of educators or teachers, learning outcomes are a process of transfer of knowledge provided by teachers to their students by following per order by following with a predetermined curriculum. The level of understanding of students can be known through evaluating learning outcomes. The assessment of students' learning outcomes can be done through evaluating learning outcomes both at the beginning The success of learning outcomes can be seen through its development of two perspectives, namely the teacher and students. In terms of students or students, learning outcomes are the results of the learning process that can be seen from the changes and mental development that leads to better behaviour of the middle or at the end of learning. Thus it can be seen the basic competencies in the mastery of the material by students, both concerning social, emotional, spiritual, and moral aspects. From some of the definitions above, it can be concluded that learning outcomes are a series of teaching and learning outcomes obtained by students while attending education as measured in the form of evaluation (Dimyati and Mudjiono, 2013).

\section{Conclusion}

Based on data from research, data processing, analysis, and discussion of data, the following conclusions can be obtained: There is no difference in pre-test learning outcomes between class $\mathrm{X}$ and class $\mathrm{Y}$. There is no difference in post-test learning outcomes between class $\mathrm{X}$ and class $\mathrm{Y}$. There are significant differences in the pre-test and post-test scores in class $\mathrm{X}$ and class $\mathrm{Y}$. Before doing the lesson, it is better if the facilitator and participants are given curriculum and modules. So that in learning there is an active interaction between participants and the facilitator. 


\section{Acknowledgments}

Thank you to the Head of Batam Health Training Center and his staff who helped from the initial data collection to the writing of this paper.

\section{References}

Amirono \& Daryanto. (2016). Evaluasi \& Penilaian Pembelajaran Kurikulum. 2013. Yogyakarta: : Penerbit Gava Media.

Arikunto, S. (2019). Fundamentals of Educational Evaluation. Jakarta: Bumi Aksara.

Arini, O. D., Rasana, R., \& Suami, N. K. (2013). Pengaruh Strategi Pembelajaran Aktif Tipe Group to Group Exchange terhadap Hasil Belajar Matematika Kelas V SD. Jurnal Mimbar PGSD, 1(1), 1-10.

Buchori, A., Setyosari, P., Dasna, I. W., Ulfa, S., Degeng, I. N., \& Sa'dijah, C. (2017). Effectiveness of Direct Instruction Learning Strategy Assisted by Mobile Augmented Reality and Achievement Motivation on Students Cognitive Learning Results. Asian Social Science Journal, 13(9), 137-144.

Cruz, S. (2015). Apps para dispositivos móveis: manual para professores, formadores e bibliotecários.

Daryanto. (2015). Education of evaluation. Jakarta: Rineka Cipta.

Dewi, M. A., Sugiarta, I. M., \& Suarsana, I. M. (2015). Penerapan Pembelajaran Kooperatif Teknik Kancing Gemerincing untuk Meningkatkan Keaktifan dan Prestasi Belajar Matematika Siswa SD. Jurnal Jurusan Pendidikan Matematika, 3(1), 1-10.

Dimyati and Mudjiono. (2013). Study and Learning. Jakarta: Rhineka Cipta.

Guzel, E. B., \& Gunhan, B. C. (2010). Prospective Mathematics Teachers' Views about Using Flash Animations in Mathematics Lessons. International Journal of Hman and Social Sciences, 5(3), 154-159.

Hartiningrum, E. S., \& Yanti, N. R. (2017). Pengaruh Model Pembelajaran Kooperatif Teknik Kancing Gemerincing Terhadap Hasil Belajar Matematika Siswa Kelas XI SMK Telekomunikasi Peterongan Jombang. Journal of Mathematics Education, 3(1), 1-8.

Karamete, A., \& Günaydin, S. (2016). Material Development to Raise Awareness of Using Smart Boards: An Example Design and Development Research. European Journal of Contemporary Education, 15(1), 114-122.

Law Number 23 Of 2014. (n.d.). Regional Government. Jakarta: Ministry of State Secretariat. Ministry Of Health. (2016). Regional Health Planning Training Module. Jakarta: Health Human Resource Training Center.

Purwanto, M. (1998). Principles and Techniques of Teaching. Bandung: CV Remaja Karya. Roger , \& Johnson, D. W. (2009). An Overview Of Cooperative Learning.

Saefudin, A. A. (2012). Pengembangan Kemampuan Berfikir Kreatif Siswa dalam Pembelajaran Matematika dengan Pendekatan Pendidikan Realistik Indonesia (PMRI). Jurnal Pendidikan Dasar Islam, 4(1), 37-48. 
Sahid, A., \& Buditjahjanto, I. A. (2013). Pengaruh Strategi Pembelajaran Group to Group Exchange terhadap Hasil Belajar Siswa dengan Motivasi Berprestasi Berbeda pada Standar Kompetensi Menerapkan Dasar-Dasar Teknik Digital. Jurnal Pendidikan Teknik Elektro, 2(2).

Sri Rusmini, et al. (2019). Educational Psychology. Yogyakarta: Yogyakarta State University. Suciati and Prasetya Irawan. (2017). Learning Theory and Motivation. Jakarta: PAU-PPAI, Open University.

Sudijono, A. (2018). Introduction to Educational Evaluation. Jakarta: Raja Grafindo Persada.

Sudjana, N. (2018). Basic and Teaching and Learning Process, page 22. Bandung: PT. Sinar Baru.

Wahyuni, L. (2015). Pengaruh Pembelajaran Active Learning Tipe Group To Group Exchange (Gge) Terhadap Kemampuan Pemahaman Konsep Matematika Siswa Kelas Viii Mtsn Koto Majidin Tahun Pelajaran 2014/2015. Jurnal Penelitian Universitas Jambi Seri Humaniora, 17(2), 19-25.

Zakaria , E., \& Iksan, Z. (2007). Promoting Cooperative Learning in Science and Mathematics Education. Eurasia Journal of Mathematics, Science \& Technology Education, 3(1), 35-39. 